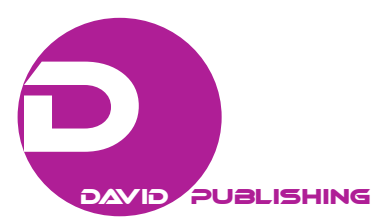

\title{
Specificities of the French Cooperative Banking Groups Facing the 2007-2012 Crisis*
}

\author{
Gilles Caire, Sophie Nivoix \\ University of Poitiers, Poitiers, France \\ Pascal Glemain \\ University of Rennes, Rennes, France
}

\begin{abstract}
In this paper, the authors compare the financial and associate membership data over the 2007-2012 period of the three French mutual and cooperative banking groups [Crédit agricole, Crédit mutuel, and BPCE (Banques populaires and Caisses d'épargne)] (see in the Appendix) with those of the two “capitalist” banking groups (BNP-Paribas and Société générale). This study is part of a broader research including other dimensions of the cooperative model. All the data used come from the annual reports of the five banking groups analyzed over the 2007-2012 period, and not from a database. Indeed, a database may raise many relevance problems related to difficulties of consolidation that are specific to cooperative groups. Even if the way to create earnings may imply the same business as in capitalist banks (loans, deposits, shareholdings, investment banking, etc.), the way to do it may be different in cooperative banks (fair conditions of borrowing, shareholdings in order to finance the economy rather than simply make capital gains, etc.). Thus, the difference between the two types of banks, as cooperative banks say, is both their final goal and the way to reach it. Meanwhile, a major external difficulty is that cooperative banks have to obey the same prudential rules as other banks whereas these norms were created for a capitalist organization and governance model. In the same way, the indivisible reserves, the steadiness of the share value, or the impossibility of external takeovers is among the main characteristics of the cooperative model and they are not taken into account by the financial analysis.
\end{abstract}

Keywords: banking risks, bank governance, cooperative model

\section{Introduction}

Since 2010, the French cooperative banks have clearly focused their communication strategies on their cooperative specificities. Indeed, since 2010, the TV advertising campaign of Crédit mutuel is based on the slogan "A bank which belongs to its customers, it’s all different” ("Une banque qui appartient à ses clients, ça change tout”). In 2012, while it is impacted by heavy losses in foreign markets and more precisely in Greece,

\footnotetext{
* Project supported: This paper is related to a collective research project over 2012-2014, about the specificities of cooperative banks in Pays de Loire (France), supported by the Observatoire régional de l'économie sociale et solidaire de la CRESS Pays de Loire, in partnership with seven cooperative banks.

Gilles Caire, associate professor in economics, University of Poitiers, Poitiers, France.

Sophie Nivoix, associate professor in management, University of Poitiers, Poitiers, France.

Pascal Glemain, associate professor in economics, University of Rennes, Rennes, France; associate professor, CERMi-University of Mons, Mons, Belgium.

Correspondence concerning this article should be addressed to Sophie Nivoix, Faculté de Droit et des sciences sociales, 2 rue Jean Carbonnier-TSA 8110086073 Poitiers cedex 09, France.
} 
Crédit agricole decided to choose as a communication guideline "A cooperative bank which boosts the local economy" and "which is committed in your area" ("Une banque coopérative qui dynamise l'économie locale" and "qui s'engage près de vous"). In the same way, Crédit coopératif explains that "We are the bankers of an idea. The idea of a finance useful for everyone” (“Nous sommes les banquiers d'une idée. L’idée d'une finance utile à tous"). Eventually, the BPCE group selected in November 2013 as institutional signature "A different kind of cooperative, bankers and insurers” (“Coopératifs, banquiers et assureurs autrement”).

These new communication orientations put forward the question of the existence of a banking cooperative model, which appeared in the second half of the 19th century and whose goal is to serve associate members by relying on responsibility, solidarity, and democracy values. The cooperative banks assert the strength of several principles: economic participation of their associates, mutual and personal responsibility, collective ownership, partly indivisible reserves, financing of real economy, proximity, local roots, rejection of the sole seek for financing return, fair sharing of profits, patient investment, sustainability, resilience, strength, stability, measurement and temperance, transmission of collective heritage to future generations...(these principles come from the three major texts of the cooperative sector: ICA 2009 ${ }^{1}$, Coop fr $2010^{2}$, and EACB $2012^{3}$ ).

Some positive specificities in banking activities come directly from these values and principles. The academic literature about cooperative banks in the recent years (e.g. Fonteyne, 2007; Ayadi, Llewellyn, Schmidt, Arbak, \& De Groen, 2010; Birchall, 2013; Groeneveld, 2013) can point out five assumed advantages of the banking cooperative model:

- the priority given to services to customers rather than pay-out to investors, a better efficiency in retail banking, a larger attention to SME, merchants, craftsmen, farmers, and low income individuals;

- activities more oriented towards real economy, more independence in financing, and less dependence towards financial markets;

- lower but steadier financial returns, a governance (managers and administrators) less focused on financial performance in the short run;

- a higher market capitalization, more sustainable, less volatile, and less risky;

- more proximity about agencies, decision taking, and investments in the local economy.

As a consequence, cooperative banks are supposed to be more resistant in crisis period and should help to stabilize the whole financial system thanks to their weight and behaviour, as well as they should favor the general economic growth. Several recent studies tested the relevance of these aspects of discourses on a worldwide level [(GABV, 2012) comparing 17 "sustainable banks" members to the $27 \mathrm{GSIFI}^{4}$ banks and to the US banks over the 2002-2011 period; Roy and Redjah (2012) analyzed the evolution of 15 financial indicators of 34 financial cooperatives of 26 countries over the 2001-2010 period], European level [Groeneveld (2013) compared a sample of 15 cooperative banking groups to the whole banking system of the countries concerned

\footnotetext{
${ }^{1}$ Déclaration de l'Alliance Coopérative Internationale sur l’Identité Coopérative Internationale, 2009. Crédit coopératif and Confédération Nationale du Crédit Mutuel are direct members of ICA (International Cooperative Alliance). Crédit coopératif, Confédération Nationale du Crédit Mutuel, Crédit agricole, and Banque populaire are members of the ICBA (International Cooperative Banks Association), sector affiliate of ICA.

2 Déclaration sur l'identité coopérative, Coop FR, 2010. BPCE Group, Crédit coopératif, Confédération Nationale du Crédit Mutuel, Crédit agricole (through the Confédération Nationale de la Mutualité, de la Coopération et du Crédit Agricoles) are members of Coop FR.

${ }^{3}$ More than a Bank, a co-operative Bank, EACB (European Association of Cooperative Banks), 2012. The French members are Confédération Nationale du Crédit Mutuel, BPCE group, Fédération Nationale du Crédit Agricole.

${ }^{4}$ Global Systemically Important Financial Institutions.
} 
over the 2002-2011 period; Birchall (2013) studied the cooperative banks of 12 European countries over the 2005-2011 period; Lemzeri, Jaeger, and Ory (2013) compared a sample of 18 cooperative banks of nine European countries to a sample of 47 other banking groups of the same countries], and French level [Ory, De Serres, and Jaeger (2012) made a comparison of the evolution of the three French cooperative groups to the two major capitalist banking groups over the 1992-1996 and 2008-2010 periods]. These studies tend to confirm the long lasting cooperative specificities, even if the gap with capitalist groups tends to shrink.

This paper compares the financial and associate membership data over the 2007-2012 period of the three French mutual and cooperative ${ }^{5}$ banking groups (Crédit agricole, Crédit mutuel, and BPCE) with those of the two "capitalist" banking groups (BNP-Paribas and Société générale). This study has about the same approach as those of Groeneveld (2013), Ory et al. (2012), and Lemzeri et al. (2013), but includes two particular aspects. First, it is part of a broader research including other dimensions of the cooperative model (price of services, advice, kind of products, customer's opinion, employees' wages, ESR policy, governance pratices, role of associates...), whose results are integrated in a collective report for the CRESS (Regional Chamber for Social and sustainable Economy) (Caire, Glémain, \& Nivoix, 2014). Second, all the data used below come from the annual reports of the five banking groups analyzed over the 2007-2012 period, and not from a database like Bankscope which as mentioned by Groeneveld raises many relevance problems related to difficulties of consolidation that are specific to cooperative groups.

The remaining of this paper is organized as follow. Section 2 presents the importance of cooperative banks in France, which is the top country in the world in this field, as depending on the indicator the authors look at, cooperative banks represent between 2/3 and 3/4 of the French banking sector. Section 3 studies the cooperative model of ownership, underlines the increasing number of associates during the crisis, and shows the evolutions of the hybridation between the cooperative and capitalist logics, as the core of the cooperative groups now represent only between $45 \%$ and $58 \%$ of the activities. Section 4 details the business models during the crisis. It compares the activity ratios of the three cooperative groups with those of the two capitalist groups, which shows the cooperative advantages: a stronger growth, an organizational and commercial efficiency, and a real priority given to real economy. Meanwhile, the changes in the agencies networks are more contrasted. Section 5 studies another aspect of the business model, i.e. the risk taking. It shows, as expected, that the share of financial market-related activities and return on equity (ROE) or return on assets (ROA) are lower in cooperative groups. Contrary to what is usually assumed, the volatility of ROE and ROA is higher in cooperative banks, and capital ratios are close to those of capitalist banks. Section 6 concludes and shows the limits of an analysis of the cooperative model based on indicators built to evaluate the performance of capitalist firms.

\section{The French Paradox: The Banking Services Market Is Dominated by Cooperation}

When the authors consider the consolidated total assets (Table 1), the three French cooperative groups belong to the top 20 of European banks ${ }^{7}$, and the only other cooperative bank in this top 20 is the Dutch group Rabobank (with 752 billion euros of assets). Crédit agricole group is the 3rd European bank (and first cooperative

\footnotetext{
${ }^{5}$ On a legal basis, in France the cooperative or mutual label of banks has no consequence on the way they operate. Thus, the authors use the words "cooperative bank" in the general meaning.

6 The authors use the words “capitalist bank" meaning that they try to maximize their return, but not in the meaning of the production factors (in this way cooperative banks are also highly capitalistic). Moreover, the words "commercial bank, Ltd company, classic bank" also apply to cooperative banks and the words "non-cooperative" also raise some problems.

7 Source: SNL’s top 50 European big bank list 2013.
} 
bank in the world) with assets value (2,008 billions) close to those of the first two banks, i.e. the British HSBC (2,041 billions), and the German Deutsche Bank (2,022 billions). One of the consequences of the weight of Crédit agricole and BPCE and their activities on the financial markets is that these two groups belong to the 28 “systemically important” banks, as well as BNP and Société générale ${ }^{8}$.

Table 1

Weight of the Cooperative Sector (2012)

\begin{tabular}{|c|c|c|c|c|c|c|c|}
\hline \multirow[t]{2}{*}{2012} & \multicolumn{3}{|c|}{ Cooperative banking groups } & \multirow[t]{2}{*}{$\begin{array}{l}\text { Share of } \\
\text { coop. sector }\end{array}$} & \multicolumn{2}{|c|}{ Capitalist banking groups } & \multirow{2}{*}{$\begin{array}{l}\begin{array}{l}\text { State-owned } \\
\text { bank }\end{array} \\
\text { Banque postale }\end{array}$} \\
\hline & Crédit agricole & Crédit mutuel & BPCE & & $\begin{array}{l}\text { Société } \\
\text { générale }\end{array}$ & BNP-Paribas & \\
\hline \multicolumn{8}{|c|}{ Consolidated data in billion euros } \\
\hline Total assets & 2,008 & 645 & 1,147 & $53 \%$ & 1,250 & 1,907 & 196 \\
\hline European ranking & 3rd & 20th & 10th & & 8th & 4th & 43th \\
\hline Revenues & 31 & 15 & 22 & $50 \%$ & 23 & 39 & 5 \\
\hline \multicolumn{8}{|l|}{ Data France } \\
\hline $\begin{array}{l}\text { Assets in } \\
\text { France/Total assets }\end{array}$ & $83 \%$ & $91 \%$ & $92 \%$ & $88 \%$ & $77 \%$ & $52 \%$ & $>99 \%{ }^{9}$ \\
\hline $\begin{array}{l}\text { Revenues France } \\
\text { /Total revenues }\end{array}$ & $82 \%{ }^{10}$ & $85 \%$ & $84 \%$ & $83 \%$ & $43 \%$ & $32 \%$ & $>99 \%$ \\
\hline $\begin{array}{l}\text { Share of revenues } \\
\text { made in France }\end{array}$ & $30 \%$ & $15 \%$ & $22 \%$ & $67 \%$ & $12 \%$ & $15 \%$ & $6 \%$ \\
\hline $\begin{array}{l}\text { employment in } \\
\text { France }\end{array}$ & 113,153 & 67,000 & 127,000 & $72 \%$ & 60,063 & 58,450 & 31,000 \\
\hline Agencies in France & $\begin{array}{l}\text { 9,090 } \\
\text { (7,013 except } \\
\text { LCL) }\end{array}$ & $\begin{array}{l}5,362 \\
(3,300 \text { except } \\
\text { CIC) }\end{array}$ & 8,000 & $\begin{array}{l}61 \% \\
(83 \% \\
\text { except post } \\
\text { offices) }\end{array}$ & 2,357 & 2,250 & $\begin{array}{l}10,000 \text { (post } \\
\text { offices) }\end{array}$ \\
\hline Clients in France & $\begin{array}{l}27 \text { millions } \\
\text { (among which } \\
\text { seven of LCL) }\end{array}$ & $\begin{array}{l}15 \text { millions } \\
\text { (among which } \\
\text { four of CIC) }\end{array}$ & $\begin{array}{l}36 \text { millions } \\
\text { (among which } \\
8.5 \text { of } \mathrm{BP} \text { and } \\
27.5 \text { of } \mathrm{CE} \text { ) }\end{array}$ & $74 \%$ & 9 millions & 7 millions & 11 millions \\
\hline
\end{tabular}

Source: Annual reports of the banking groups.

The three cooperative groups represent half of the French banking industry ${ }^{11}$, as they own 3,800 billion euros (or 53\%) of its total assets, and exhibit 68 billion (or 50\%) of its revenues (measuring the contribution of bank to the GDP).

If looking exclusively at the activity in France ${ }^{12}$, the cooperative sector is overwhelming: $67 \%$ of the net operating income made in France, $72 \%$ of the employment, $74 \%$ of the customers, and $83 \%$ of banking agencies (except post offices). Indeed, the three groups are focused on the domestic market—on average, $83 \%$ of the revenues are made in France and $88 \%$ of the assets are located there—while Société générale and BNP-Paribas are more internationally-oriented, with respectively only $43 \%$ and $32 \%$ of their revenues made in France.

According to the indicator the authors choose (net operating profit, employment, agencies, and customers),

\footnotetext{
${ }^{8} 2012$ data of Conseil de stabilité financière (FSB). On 1 (low) to 5 (high) risk scale BNP stands at 3 and CA, BPCE and SG at 1.

9 The activities of the group is done nearly exclusively in France, except the foreign subsidiaries of CNP Assurances.

${ }^{10}$ From 2007 to 2011, this coefficient was about 72\%. The difficulties of Crédit agricole in international business, mainly in Greece, and the selling of the related activities explain this sharp increase.

11 The share of the cooperative sector is computed with the data of the six banking groups the authors study. The other banks in France (subsidiaries of foreign banks like HSBC France, mutual insurance companies like Axa Banque or Groupama banque, automobile manufacturer like Renault or retailing groupe like Carrefour...) represent about $5 \%$ of the retail bank market.

12 According to the place of accounting registration of the activities.
} 
the services provided by cooperative banks represent between 2/3 and 3/4 of French market.

\section{Position of Associate Membership in the “Cooperative Capitalism”}

Cooperative firms are based on the association of persons. Considering the number of capital owners, 23 million people are concerned by banking associate membership, meaning 45\% of French population over 15 years old.

Since 2002, the number of associates (share owners) sharply increased in the three cooperative groups (+ $29 \%$ in Crédit mutuel, $+35 \%$ in Crédit agricole, and $+76 \%$ in BPCE) (Figure 1). Overall, the number of associates climbed from 16.3 million in 2002 to 23.7 million in 2013, representing a share of French people over 15 increasing from $33 \%$ to $45 \%$. This means that today nearly half of French adults are concerned by banking associate membership. Such an evolution may be seen as Groeneveld (2013) said at the European level as a sign of attractivity and success of the cooperative banking model, showing the confidence and satisfaction of the customers. This can also be explained in the French case by a very proactive policy of the three groups, with the double goal of democratic legitimacy and cheap equity strengthening (Caire \& Nivoix, 2012). Anyway, the associate membership means a kind of double capital, related to both share capital (meaning equity ${ }^{13}$ ) and real social capital in the sens of Putnam.

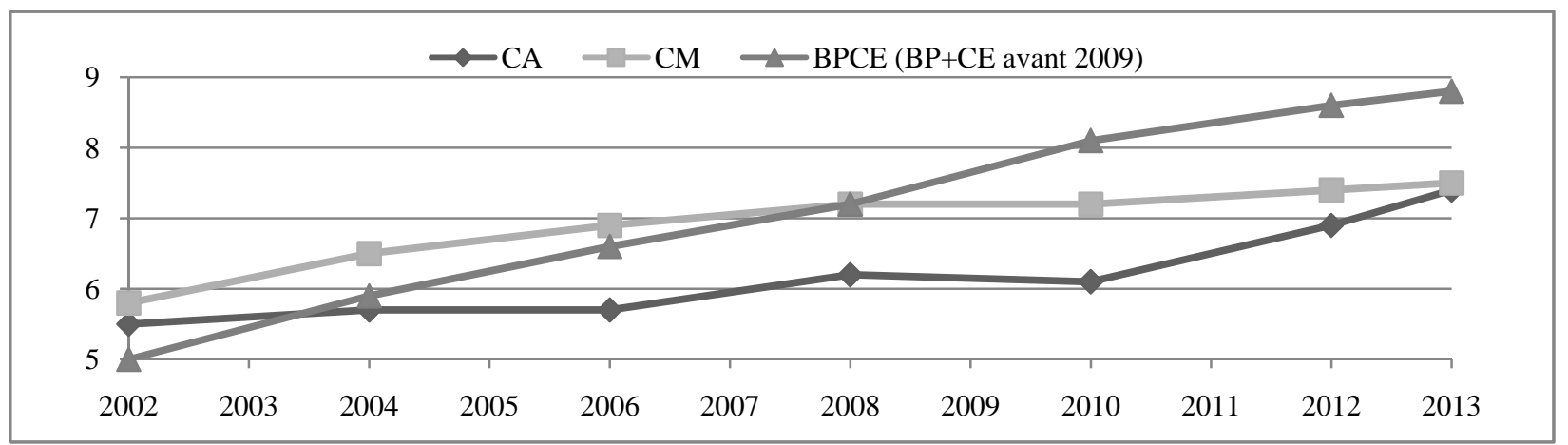

Figure 1. Evolution of the number of associates (in millions) of the three French cooperative groups. Source: Annual reports of banks.

Table 2

Number of Bank “Owners” in France

\begin{tabular}{|c|c|c|c|c|c|c|}
\hline & Crédit agricole & Crédit mutuel & BPCE & Société générale & BNP-Paribas & Banque postale \\
\hline $\begin{array}{l}\text { Associates in } \\
2012\end{array}$ & 6.9 millions & 7.4 millions & 8.6 millions & - & - & - \\
\hline $\begin{array}{l}\text { Shareholders } \\
\text { (estimated) }\end{array}$ & $\begin{array}{l}1.2 \text { million } \\
\text { (CASA) }\end{array}$ & na $^{14}$ & $\begin{array}{l}1 \text { million } \\
\text { (Natixis) }\end{array}$ & 90,000 & 20,000 & $\begin{array}{l}1 \\
\text { (La Poste) }\end{array}$ \\
\hline
\end{tabular}

More surprisingly, the number of individual shareholders (1.2 million for CASA, one million for Natixis) is out of proportion with those of capitalist banks (90,000 for Société générale, 20,000 for BNP), and is a result of large marketing campaigns towards associates and customers in 2001 for CASA and in 2006 for Natixis ${ }^{15}$ (Table 2). Thus, paradoxically, these two cooperative groups take a major part in the "people" shareholding in France, as the

\footnotetext{
13 The European cooperative banks had hard times to make Basel committee recognize that social shares are equivalent to equity and should then be integrated in Tier 1 ratio.

$141.15 \%$ of CIC equity is owned by individuals but the number of shareholders is not available.

152.5 million individual shareholders bought CASA stocks in 2001 and 2.8 million bought Natixis stocks in 2006.
} 
total number of shareholders-except employees shareholding-is estimated around 4.2 million (source: Baromètre épargne TNS SOFRES, january 2013).

Regarding the capital structure the analysis is harder. The organization charts of cooperative banks evolved progressively since the mid-80s and are now particularly complex, mixing both the cooperative and the capitalist logic (see appendix for the three French groups). This hybrid trend happened on five levels, as this paper will show below with Crédit agricole.

(1) On the business segments, product line, and customers level: each cooperative network was historically specialized on specific customers and was allowed by the State to operate some specialized activites. Today, the universal bank model is relevant for cooperative banks as well as for capitalist banks. Whereas, its business was previously limited to farmers and rural people, Crédit Agricole was allowed in 1982 to give personal loans and housing loans to any person in the country. In 1990, this bank lost the monopoly of subsidized loans to agriculture but in 1991 the financing of large firms becomes possible for the bank. Finally, on 1st January 2009, the monopoly of the distribution of the Livret A (saving account) of the Caisse d'épargne, Crédit mutuel, and La Poste is abolished ${ }^{16}$. From this moment on, Crédit agricole completed its conversion into a universal bank ${ }^{17}$ and was freed from a State control which had lasted for over a century ${ }^{18}$.

(2) On the status level: the mutualization law of 18th January 1988 enabled the transformation of CNCA, a state-owned company, into a limited company. The shares were sold by the State to regional banks (90\%) and employees (10\%). Crédit Agricole then became fully independent, which ended the mandatory charging by the State on its profits. In the same way, the other group headquarters, like BPCE, federal banks, and the Banque fédérative du Crédit mutuel are now limited companies. Moreover, nearly all technical and specialized subsidiaries of the groups also are limited companies.

(3) On external growth level: at a national level Crédit agricole uses its excess cash flows and takes advantage of the difficulties of the capitalist and state-owned banking sector at that time to buy Indosuez bank in 1996 and Sofinco in 1999 to become a shareholder of Crédit Lyonnais in 1999 and control it fully from 2003 on. At the international level, some shareholdings were taken in Banco Ambrosiano Veneto (Italy) in 1989 and Banco Espirito Santo (Portugal) in 1991, and later with its development plan of 2006-2008 Crédit agricole achieved many acquisitions in Egypt, Ukrain, Serbia, Greece, Italy, Poland, Portugal, Morocco, and so on. Crédit mutuel took control of CIC in 1998 and Cofidis in 2008, but it is more cautious in international markets; although it operates in Italy, Spain, or Germany. All these subsidiaries are limited companies.

(4) On the stock market level: CNCA made its initial public offering under the name of Crédit Agricole SA in 2001, and there was a merge of the investment banks Ixis CIB for Caisses d'épargne and Natexis Banques Populaires, which ended with another IPO in 2006. Nevertheless, the cooperative core still controls both companies, the floating being respectively at $43.7 \%$ and $27.7 \%$. Crédit mutuel did not follow this trend as only $1.15 \%$ of equity of CIC is floating.

(5) On the use of new cooperative ${ }^{19}$ instruments level: the investment cooperative certificates (CCI) created by the 17 June 1987 Act on savings, and the associates cooperative certificates (CCA) created by the 13 July 1992

\footnotetext{
${ }^{16}$ At the beginning of 2005, Crédit Agricole, followed later by BNP-Paribas, Société Générale, Banque Populaire, and ING Direct, filed a compaint at the European Commission against these special pay-out possibilities.

17 Universal bank and insurance activities even for the three cooperative groups.

18 It can be mentioned that up to the 1990s, the agency opening by Crédit Mutuel required an administrative authorization and was limited by an annual quota.

${ }^{19}$ The whole amount of these assets cannot be over $50 \%$ of the share capital of the cooperative (and not more than 35\% of voting rights).
} 
Act on the modernization of cooperative firms. By nature, these two instruments are hybrids, as they mix cooperative principles (underlined in Table 3) and capitalist ones (in italic in Table 3). The authors have to mention that these instruments were conceived in order to improve the attractivity of cooperative investment, considering return and right to share reserves, with the objective to ease the development of all cooperative firms. Meanwhile, Crédit agricole and BPCE also used these tools to modify the traditional inverted pyramid model of cooperative banks: CASA owns $25 \%$ to $29 \%$ of the shares of each of the 38 Regional banks ${ }^{20}$ through CCA and CCI assets; Natixis, the listed holding of BPCE, owns $20 \%$ of each of the 19 Banques populaires and 17 Caisses d'épargne ${ }^{21}$.

Table 3

Compared Ownership Instruments

\begin{tabular}{|c|c|c|c|c|c|}
\hline & Stock & Social share (called A) & $\begin{array}{l}\text { Social share with preferred } \\
\text { interets (called B or C) } \\
\text { (CM, Crédit coop) }\end{array}$ & $\mathrm{CCI}$ & CCA \\
\hline Subscription & Free & $\begin{array}{l}\text { Customer (CA, CE) } \\
\text { Free (BP, CM) }\end{array}$ & Associate & Free & Associate \\
\hline $\begin{array}{l}\text { Maximal } \\
\text { amount per } \\
\text { person }\end{array}$ & No & $\begin{array}{l}\text { No }(\mathrm{CE}) \\
\text { Yes (CA: } 5,000 \text { or } 7,500 € \\
\text { depending on regional banks; } \\
\text { BP: } 5,000 \text { to } 10,000 € \\
\text { depending on regional banks) }\end{array}$ & $50,000 €($ share B or C) & No & No \\
\hline $\begin{array}{l}\text { Place and } \\
\text { voting right }\end{array}$ & $\begin{array}{l}\text { Annual assembly } \\
\text { of the limited } \\
\text { company } \\
\text { Proportional to } \\
\text { owned stocks }\end{array}$ & $\begin{array}{l}\text { Annual assembly pf the local } \\
\text { bank (regional bank for BP) } \\
\text { one person = one voting right }\end{array}$ & No voting right & No voting right & No voting right \\
\hline Earnings & Free dividend & $\begin{array}{l}\text { Maximum interest at the } \\
\text { average rate of limited } \\
\text { companies' bonds (for CA, } \\
\text { CE, BP) } \\
\text { No earnings (for CM) }\end{array}$ & $\begin{array}{l}\text { Maximum interest at the } \\
\text { average rate of limited } \\
\text { companies' bonds } \\
\text { Minimum interest equal to } \\
\text { the one of shares }\end{array}$ & Free interest & $\begin{array}{l}\text { Free dividend and } \\
\text { at least equal to the } \\
\text { one of shares }\end{array}$ \\
\hline Selling & In the market & $\begin{array}{l}\text { Limited selling, buying by the } \\
\text { bank }\end{array}$ & $\begin{array}{l}\text { Limited selling, possible } \\
\text { agreement between } \\
\text { associates with a prior } \\
\text { notice of three months for } \\
\text { B and five years for C } \\
\end{array}$ & In the market & $\underline{\text { Selling in order }}$ \\
\hline Price & $\begin{array}{l}\text { Price of listed } \\
\text { stock }\end{array}$ & Nominal value ${ }^{23}$ & Nominal value & $\begin{array}{l}\text { Variable price } \\
\text { (quotation) }\end{array}$ & $\begin{array}{l}\text { Variable price } \\
(\text { annual assembly) })^{24}\end{array}$ \\
\hline Liquidation & $\begin{array}{l}\text { Right on net assets } \\
\text { and share of } \\
\text { liquidation surplus }\end{array}$ & \multicolumn{2}{|c|}{$\begin{array}{l}\text { After nominal refunding, no right on net assets, no share of } \\
\text { liquidation surplus }\end{array}$} & $\begin{array}{l}\text { Right on net } \\
\text { assets and share } \\
\text { of liquidation } \\
\text { surplus }\end{array}$ & $\begin{array}{l}\text { Right on net assets } \\
\text { and share of } \\
\text { liquidation surplus }\end{array}$ \\
\hline
\end{tabular}

20 The 39th is the one of Corsica and is under $100 \%$ control of CASA.

${ }^{21}$ In 2013, BPCE bought these CCI for 12 billion euros from Natixis. These 12 billion enables Natixis both to refund its debt to its mother company and give two billion extraordinary dividends to its shareholders. Inside the network this change is presented as a structure simplification of the whole BPCE group, as the associates of the regional banks of banques populaires and caisses d'épargne will own $100 \%$ of their regional bank.

${ }^{22}$ In Banques populaires regional banks, the voting right is proportional to the number of shares owned. Though, at the annual assemblies an associate cannot own alone more than $0.25 \%$ of the total number of voting rights related to the bank shares (art L512-5 Code monétaire et financier).

${ }^{23}$ The 1992 Act allows cooperative banks to reassess the nominal value of the shares or the distribution of free shares through incorporation to the share capital of amounts taken from the reserves. Only Banques populaires regional banks used this possibility.

${ }^{24}$ In Crédit agricole, the acquired financial assets are valuated every six months, according to the evolution of the results of the regional banks. This valuation requires the approval of the ordinary annual assembly. 
Table 4

Share of Revenues of Regional Banks (Cooperative Core) in the Total Revenues of the Groups (2012)

\begin{tabular}{lll}
\hline Crédit agricole & Crédit mutuel & BPCE \\
\hline $46 \%$ & $45 \%$ & $58 \%$ \\
\hline
\end{tabular}

Source: annual reports of banks.

The cooperative core still controls the whole group and the banks remain out of reach of a takeover bid. It can then analyze the present situation as positive mix of the capitalist power and the cooperative proximity, as the result of a necessary "glocal” strategy (Olivier Pastré in Rapport d'activité et de développement durable 2012, BPCE). But this ownership hybridation raises a problem of identification of the goals and of value sharing between the different kind of equity owners (associates, shareholders, and CCI or CCA owners), but also between regional and national bank (power transfer toward the head of the network).

In a financial market crisis period, the banks of the network have to make profits to please the group shareholders. Indeed, considering Crédit agricole, Pourchet (2011) pointed out that the pay-out to shareholders during 2008, 2009, and 2010 increased strongly: "Despite the sharp drop of the group net earnings, the management decided to maintain the dividend pay-out and dedicated $98 \%$ of its net earnings to shareholders in 2008, $93 \%$ in 2009 , and $85 \%$ in 2010 " (the percentage was between $35 \%$ and $49 \%$ during the period of 2001-2007). Moreover, while studying the building of net earnings of Crédit Agricole group by business lines, he noticed that over the 2001-2007 period:

The technical subsidiaries of the group ensure the dividend pay-out to shareholders, but over the second period (2008-2010), the dividend pay-out was possible only thanks to the net earnings of the consolidated regional banks up to $25 \%$ in CASA. We can say that the associates of the 39 regional banks of Crédit Agricole enabled the dividend pay-out to the shareholders. (Pourchet, 2011)

In 2011 and 2012, as the group’s net earnings were heavily negative (loss of 1.2 billion in 2011, loss of 6.4 billion in 2011), there was no more pay-out, whereas, the earnings related to shares were maintained (generally between $2.5 \%$ and $3 \%$ depending on the regional banks).

Moreover, as Ory et al. (2012) pointed out, the hybridization phenomenon also exists in the evolution of the prudential regulation, the use of financial analysis standardized tools, performance measures, reporting, rating, and management control.

\section{Business Model: Banking Activities Dynamics}

In order to have a "cooperativist” reading of the financial accounts of banks, as noticed by Ory, Gurtner, and Jaeger (2006), three items are needed to be taken into account:

- When there are only limited companies, the performance criterion is fairly easy to use: it is related to the shareholder; the firm has only one goal: Return On Equity maximization. (...) In the cas of a consumption cooperative, there may be many goals.

- The usual ratios used in financial analysis have to be looked at cautiously: a fees drop or an increase in services quality may result in an increase in the income ratio (operating expenses/operating income) and/or by a decline of ROE, and be too rapidly interpreted as a lower efficiency and performance.

- It is necessary to center the study on the network aspect instead of the particular parts of it (limited companies versus cooperative forms) (...) because the clearing of operations and cash, the definition of strategic orientations and governance happen at the national level for al the network. Moreover, there are cross-shareholdings between firms of the same network. (Ory et al., 2006) 
Since the beginning of the financial crisis, cooperative groups were more dynamic than capitalist banks, if total assets are considered, as well as revenues, employment, credit allocation, or deposit collection (Table 5). Only equity increased at a lower pace, but as BNP and Société générale exhibited smaller equity ratios in 2007 it was harder for them to adjust to Basel II and III framework. This dynamic can be seen at the market share level as the three cooperative groups continued to increase slightly in both deposit and credit markets.

Table 5

Evolution of Activity Ratios Over 2007-2012

\begin{tabular}{|c|c|c|c|c|}
\hline & \multicolumn{2}{|c|}{$\mathrm{CA}+\mathrm{BPCE}+\mathrm{CM}$} & \multicolumn{2}{|c|}{$\mathrm{BNP}+\mathrm{SG}$} \\
\hline & 2007 & 2012 & 2007 & 2012 \\
\hline \multicolumn{5}{|l|}{ Growth over 2007/2012 } \\
\hline Annual growth rate of assets & $7.0 \%$ & & $3.1 \%$ & \\
\hline Annual growth rate of revenues & $5.7 \%$ & & $3.3 \%$ & \\
\hline Annual growth rate of employment & $5.5 \%$ & & $3.2 \%$ & \\
\hline Annual growth rate of credits & $7.8 \%$ & & $5.5 \%$ & \\
\hline Annual growth rate of deposits & $8.7 \%$ & & $7.3 \%$ & \\
\hline Annual growth rate of equity & $8.7 \%$ & & $10.7 \%$ & \\
\hline \multicolumn{5}{|l|}{ Organizational and commercial efficiency } \\
\hline Revenues/Number of employees & $224,319 €$ & $226,308 €$ & $180,882 €$ & $181,521 €$ \\
\hline Employee expenses/Revenues & 0.363 & 0.393 & 0.364 & 0.398 \\
\hline Employee expenses/Number of employees & $81,367 €$ & $88,930 €$ & $65,840 €$ & $72,303 €$ \\
\hline Credit market share (over the five groups) & $58 \%$ & $60 \%$ & $42 \%$ & $40 \%$ \\
\hline Deposit market share (over the five groups) & $56 \%$ & $57 \%$ & $44 \%$ & $43 \%$ \\
\hline \multicolumn{5}{|l|}{ Priority to real economy } \\
\hline Loans /Total assets & 0.402 & 0.419 & 0.277 & 0.311 \\
\hline Deposits/Total assets & 0.304 & 0.330 & 0.228 & 0.278 \\
\hline Cost of risk/Revenues & 0.048 & 0.122 & 0.048 & 0.136 \\
\hline
\end{tabular}

Source: authors' calculation and annual reports of banks.

If looking at the human resources employed to operate these activities, it sees that the expenses related to employees are fairly the same in the two kinds of banks when compared them to the revenues. Nevertheless, this apparently homogenous situation in all banks hides two major differences. On one hand, cooperative banks exhibit employees' expenses per person that are larger than in the two other banks (more than 15,000 euros higher, without change between 2007 and 2012). On the other hand, they have a revenue per employee that is also larger (nearly 40,000 euros, also steady between 2007 and 2012). Several explanations can be given for these outcomes: cooperative banks may have on average better paid and more efficient employees, capitalist banks may be more active (in France or abroad) in activities where price competition is strong. Another explanation would be that capitalist banks have more employee consuming activities, or activities that create a few revenues, or even, in a simpler way, cooperative banks have based their activity growth efforts on financially better motivated employees and may be more skilled. These explanations may help to confirm the efficiency hypothesis of the cooperative model in banking business.

Considering the basic banking activity, i.e. deposit collection and credit allocation, it can be noticed that credit/total assets ratios increased in all banks between 2007 and 2012. This means that some refocusing of the activities did happen after the subprimes crisis, despite some decline of these ratios for several banks in 2012. The authors can also point out that cooperative banks exhibit clearly higher ratios, indicating that their activity is more 
oriented toward the real economy and the direct needs of their customers. This result shows that the cooperative business model is indeed used by cooperative banks, which are-according to this viewpoint—consistent with the values they display (more specifically the financing of real economy and its development).

The density of the agencies network is another frequently underlined characteristic of cooperative banks. When looking at the evolutions between 2007 and 2012, there is no systematic difference in the evolution of cooperative and capitalist banks. Each network seems to develop its own strategies. Nevertheless, the results indicate that the two historically more developed networks did reduce the number of their agencies: marginally for Crédit agricole $(-0.2 \%)$, which remains the leader of agencies network, and more importantly for Caisse d'épargne (-3\%). This is certainly one of the effects of the opening of the access to Livret A saving accounts. What is also worth to be mentioned is the strong growth of the number of Banques populaires agencies (+16\%), Crédit mutuel (+6\%), and also Société générale (+6\% as shown in Table 6).

Table 6

Evolution of the Agencies Network Over 2007-2012

\begin{tabular}{lllllllll}
\hline Agencies in France & CA* & CM & CE & BP & LCL & CIC & BNP & SG \\
\hline 2007 & 7,025 & 3,100 & 4,352 & 2,880 & 2,064 & 2,055 & 2,200 & 2,997 \\
2012 & 7,013 & 3,300 & 4,219 & 3,338 & 2,077 & 2,062 & 2,200 & 3,176 \\
Evolution & $-0.2 \%$ & $+6 \%$ & $-3 \%$ & $+16 \%$ & $+1 \%$ & $+0.3 \%$ & $0 \%$ & $+6 \%$ \\
\hline
\end{tabular}

Note. * cooperative branch only.

\section{Business Model: The Risk Taking}

It is also important to check if the growth of cooperative banks has not been completed thanks to an excess risk taking. The cost of risk/revenues ratio, in which value is easier to analyze than one of cost of risk/operating revenues, which may be negative because of its denominator. This risk indicator, which was similar for the two kinds of banks in 2007, had increased significantly five years later, especially for capitalist banks. This evolution comes partly from more constraining accounting rules: three pillars ${ }^{25}$ of Basel III, IFRS 4, IFRS 7, and IAS 1 norms. Nevertheless, the average value of this ratio was the same in the medium term for all banks as it reached $14.35 \%$ for cooperative banks over the $2007-2012$ period and $14.77 \%$ for the others. Thus, this study shows that the development of the cooperative bank activities in the recent years did not come from larger risk taking, but from a more important share of basic financing activities. Here again, the cooperative banks behave according to the key characteristics of their business model, particularly concerning sustainability, and stability.

These results do not confirm the trend pointed out by Ory et al. (2012) up to 2010, which indicated a greater hybridization of the activities of cooperative banks, and a behavior and a volatility more and more close to what can be see in capitalist banks.

Consistently with what is mentioned above, Figure 2 shows that the share of activities related to financial markets (asset management and financing and investment banking) in the revenues is globally smaller in cooperative groups. The spreads are very clear, notably for Crédit mutuel which financial markets related activity are very minor.

\footnotetext{
25 Pillar 1 is about the minimal requirements of equity required by the bank, pillar 2 details the prudential surveillance process, and pillar 3 is about market discipline.
} 


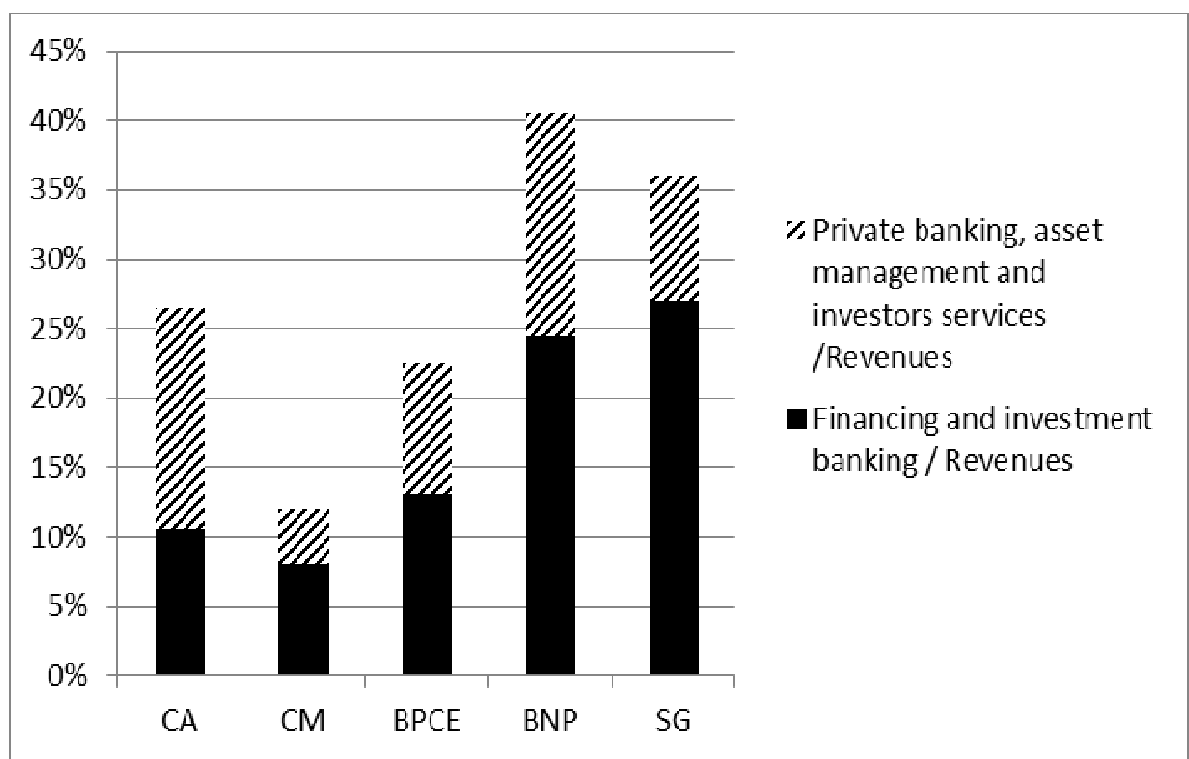

Figure 2. Share of activities related to financial markets in the revenues (fiscal year 2012). Source: authors and annual reports.

The share of activities related to financial markets compared to gross operating profit instead of revenues gives the same result, meaning a lower importance for cooperative banks (Figure 3$)^{26}$. However, the differences are less sharp and cooperative banks tend to have better gross operating profit in their market activities than other banks, for which these activities seem to be less profit generating (for instance Crédit mutuel reached a 20\% share of financial market related activities when consider the gross operating profit versus only $12 \%$ share of its revenues).

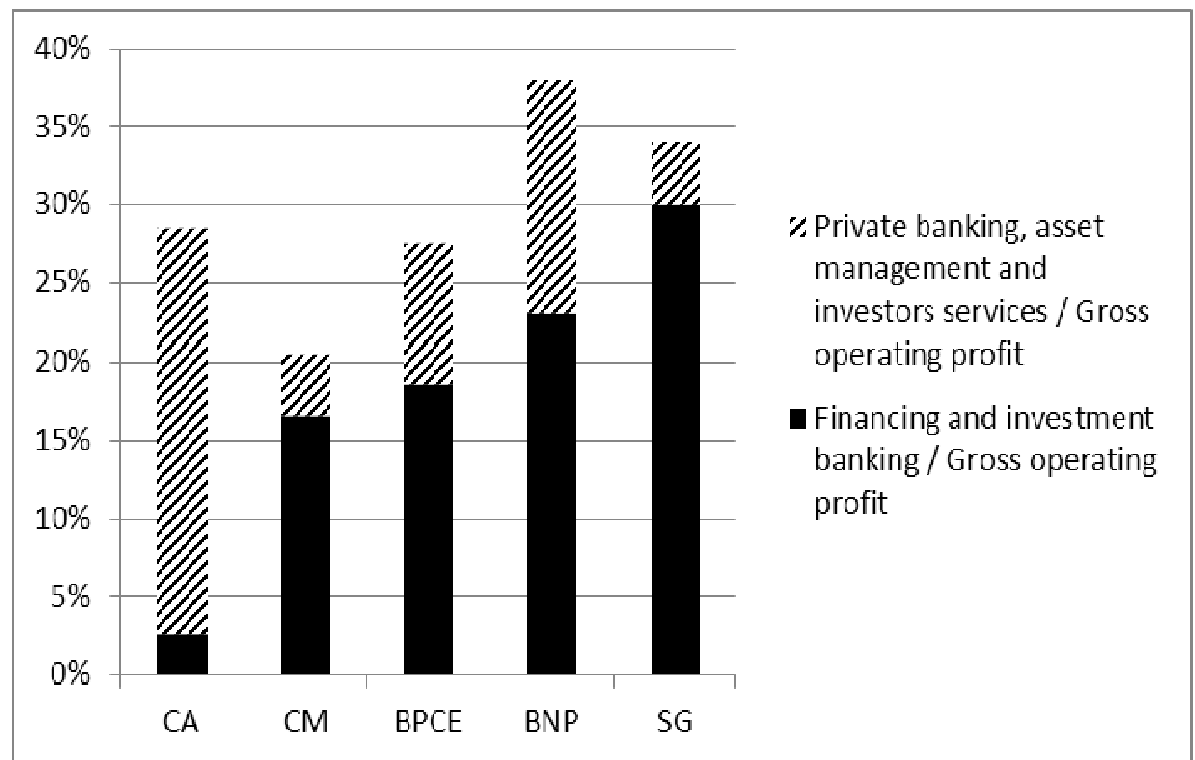

Figure 3. Share of activities related to financial markets in the gross operating profit (fiscal year 2012). Source: authors and annual reports.

In a related way, it is interesting to wonder about the use of tax heavens. Except Crédit mutuel, the two other cooperative banks (Crédit agricole and BPCE) do widely use tax heavens (Table 7), if the definition of tax heaven

${ }^{26}$ These two figures show only the year 2012 and it would be interesting to look at the other years. 
is larger than the very limited list of the $\mathrm{OECD}^{27}$. However, the number of subsidiaries does not systematically show the number of transactions made by these subsidiaries and their financial value, and unfortunately, it is obviously impossible to obtain such details.

Table 7

Number of Bank Subsidiaries in the Tax Heavens

\begin{tabular}{lllllll}
\hline & \multicolumn{1}{c}{ Crédit agricole } & Crédit mutuel & BPCE & $\begin{array}{l}\text { Société } \\
\text { générale }\end{array}$ & BNP-Paribas & Banque postale \\
\hline $\begin{array}{llllll}\text { 2010 list of the Tax Justice } \\
\text { Network }\end{array}$ & 107 & 11 & 90 & 40 & 347 & 1 \\
2012 list of CCFD & 86 & $\mathrm{Na}$ & 20 & 49 & 214 & $\mathrm{Na}$ \\
CPO first level subsidiaries & 37 & $\mathrm{Na}$ & $\mathrm{Na}$ & 31 & 118 & $\mathrm{Na}$ \\
CPO subsidiaries up to rank 10th & 150 & $\mathrm{Na}$ & $\mathrm{Na}$ & 91 & 334 & $\mathrm{Na}$ \\
\hline
\end{tabular}

In order to analyze the sustainability more precisely and the banks' orientation in the long run, it is useful to look at several indicators about equity soundness and return in Table 8. The figures show that after a major increase the equity/total assets ratio is now higher in capitalist banks. Nevertheless, the Tier 1 (share capital included preferred shares and convertible or perpetuity bonds, reserves, and balance brought forward, divided by risk-weighted total assets) and Core Tier 1 (share capital alone, reserves, and balance brought forward, divided by risk-weighted total assets) solvency ratios remain on average higher ${ }^{29}$ in cooperative banks.

Table 8

Equity Soundness and Return Over 2007-2012

\begin{tabular}{|c|c|c|c|c|}
\hline \multirow[b]{2}{*}{ Equity soundness } & \multicolumn{2}{|c|}{$\mathrm{CA}+\mathrm{BPCE}+\mathrm{CM}$} & \multicolumn{2}{|c|}{$\mathrm{BNP}+\mathrm{SG}$} \\
\hline & 2007 & 2012 & 2007 & 2012 \\
\hline Equity/Total assets & $3.9 \%$ & $4.1 \%$ & $3.2 \%$ & $4.6 \%$ \\
\hline Core Tier 1 average & & 12.3 & & 10.3 \\
\hline Tier 1 average & 8.7 & 13.0 & 7.6 & 13.0 \\
\hline Return $^{30}$ & \multicolumn{2}{|l|}{ over 2005-2012 } & \multicolumn{2}{|c|}{ over 2005-2012 } \\
\hline Return on assets (= operating income/total assets) & \multicolumn{2}{|l|}{$0.34 \%$} & \multicolumn{2}{|l|}{$0.47 \%$} \\
\hline Standard deviation of ROA & \multicolumn{2}{|l|}{$0.30 \%$} & \multicolumn{2}{|l|}{$0.19 \%$} \\
\hline Standard deviation/average (ROA) & \multicolumn{2}{|l|}{0.88} & \multicolumn{2}{|l|}{0.40} \\
\hline Return on equity (= net earnings/equity) & \multicolumn{2}{|l|}{$6.2 \%$} & \multicolumn{2}{|l|}{$9.8 \%$} \\
\hline Standard deviation of ROE & \multicolumn{2}{|l|}{$8.2 \%$} & \multicolumn{2}{|l|}{$3.9 \%$} \\
\hline Standard deviation/average (ROE) & \multicolumn{2}{|l|}{1.32} & \multicolumn{2}{|l|}{0.39} \\
\hline
\end{tabular}

Considering the return indicators, the results show that both ROA and ROE are lower in cooperative groups. Moreover, the standard deviation of these indicators is higher in cooperative banks, which indicates a larger variability of returns during the period. Contrary to what has been noticed above, such a result is consistent with the conclusions of Ory et al. (2012). A negative way to analyze would be to conclude that cooperative banks

\footnotetext{
${ }^{27}$ For the OECD in 2012: no country in the black list, 23 in grey list; 60 opaque territories list mentioned by the Tax Justice Network (TJN), which is also used by the CCFD (Comité Catholique contre la Faim et pour le Développement); 53 territories list for the CPO (Conseil des prélèvements obligatoires).

28 The Deutsche Bank has 768 subsidiaries in tax heavens, and HSBC has 136.

29 The Banque Fédérative du Crédit Mutuel is considered byr Global finance (April 2013) as one of the 50 safest worldwide banks. It is ranked 38th, and the two other ranked French banks are CDC at rank 7th and Banque Postale at rank 44th. Two other cooperative banks are also ranked: Rabobank at rank 10th and Desjardin at rank 23th.

${ }^{30}$ The data are the averages weighted by the total assets of each bank.
} 
exhibit small profits if considering the economic and financial means they use, and that it indicates a lower economic efficiency. However, as this viewpoint is not confirmed by the results about employee expenses given in Table 5 and as the banking sector is fairly unconcerned by cost killing as industry does, this study is more positively oriented. Indeed, it is important to keep in mind that ROE is mainly a shareholder dedicated indicator, and thus it is relevant for stock companies which try to maximize their stockholder value. Considering cooperative banks, the earnings given to shares do not follow the stockholder logic, these banks aim at a fair sharing of profits and associates have a limited interest in share capital. As a consequence, a weaker ROE in cooperative banks than in capitalist banks should not be considered as a problem (Figure 4). On the contrary, a larger volatility of this return over the studied period is an issue.

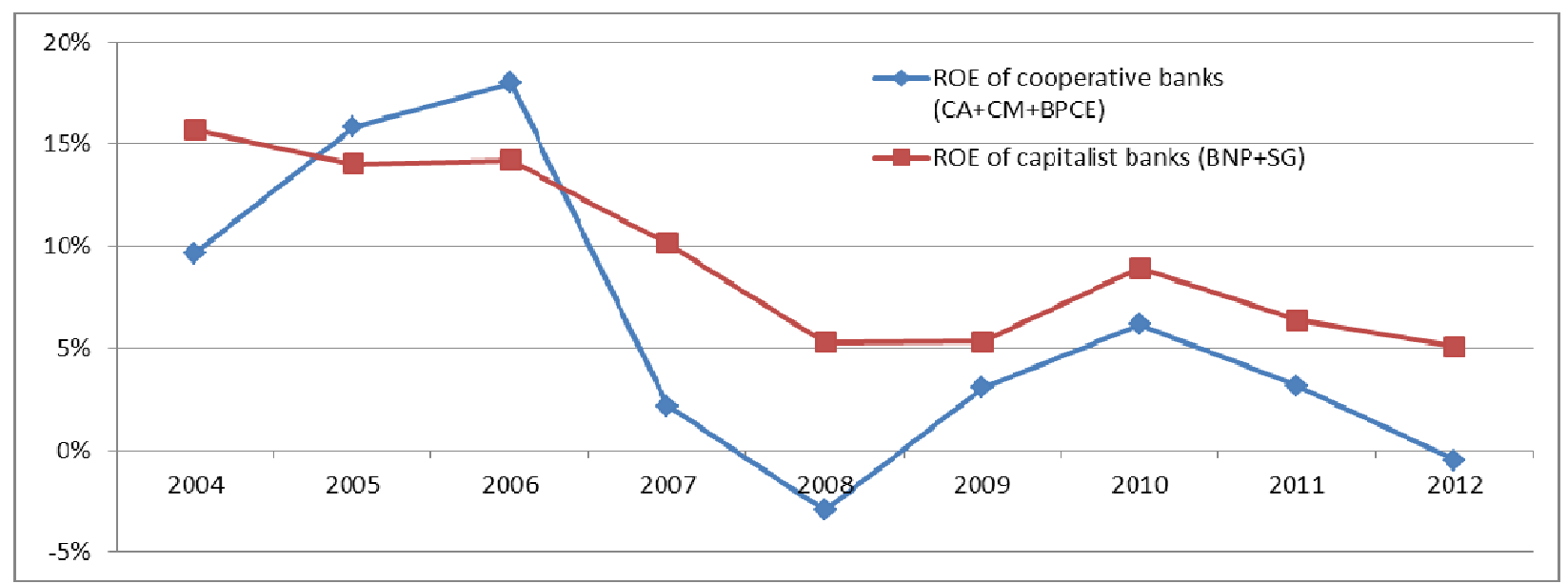

Figure 4. ROE in French banks over the 2005-2012 period. Source: authors and annual reports.

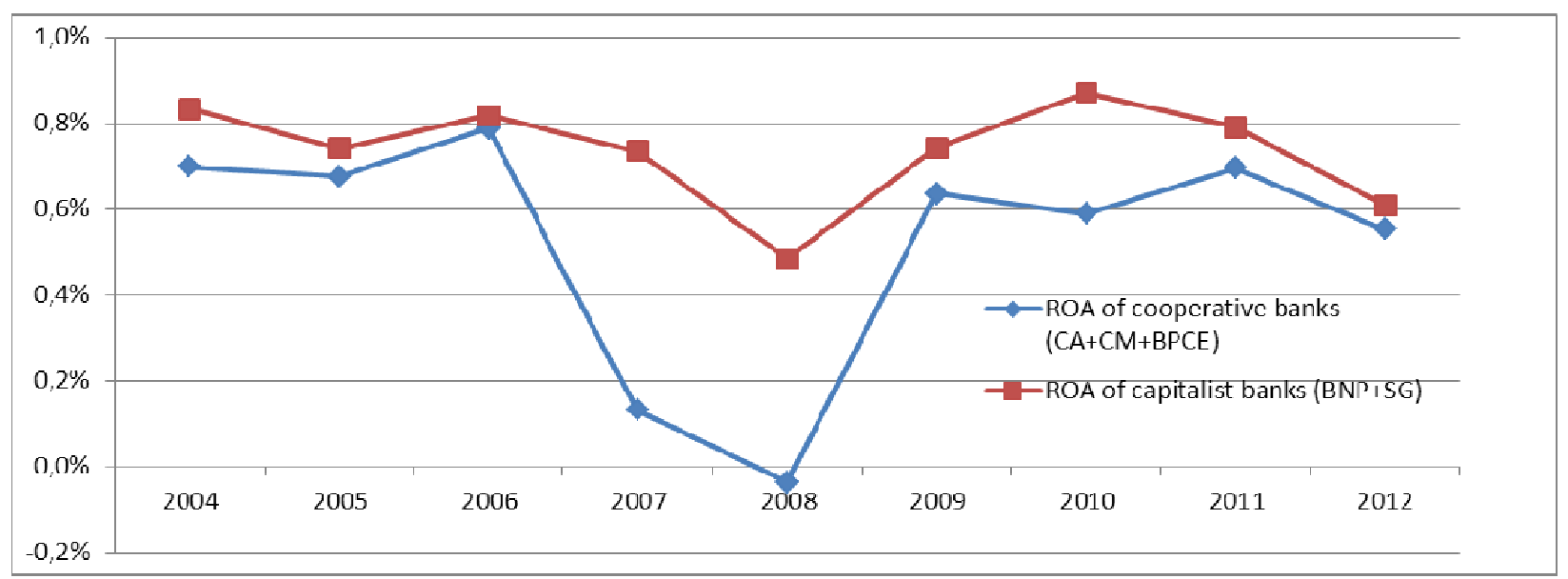

Figure 5. ROA of French banks over the 2005-2012 period. Source: authors and annual reports.

As for the ROA, even if this indicator can be applied to all banks with the same logic, the way it can be used for cooperative banks has to be qualified. Indeed, the comparison given by Figure 5 seems to mean that the subprimes crisis hit the cooperative banks harder, even if the values themselves are fairly low (nearly all of them are between $0.2 \%$ and $0.6 \%$ ). However, in a crisis period, a fall of the operating result may indicate a more cautious commercial policy or a more systematic depreciation of non-performing loans (what unfortunately cannot be checked here because of too numerous financial reports of subsidiaries that should analyze in detail). 
Thus, an apparently negative outcome about activity may be consistent with a careful strategy in the long run and the goal of a sustainable activity.

\section{Conclusion}

This study shows that the cooperative way should be different not simply on the way to make profits but more in the way to give them to associates (Ory et al., 2012). Another important aspect is that even if the way to create earnings may imply the same business as in capitalist banks (loans, deposits, shareholdings, investment banking, etc.), the way to do it may be different (fair conditions of borrowing, shareholdings in order to finance the economy rather than only make capital gains, etc.). Thus, the difference between the two types of banks, as cooperative banks say, is both their final goal and the way to reach it. However, a major external difficulty is that cooperative banks have to obey the same prudential rules as other banks whereas these norms were created for a capitalist organization and governance model.

This is why it is important to mention that one main limit of the analysis of the specificities of cooperative banks comes from performance indicators that are built for capitalist banks. The use of ROA, ROE, solvency ratios or operating costs, and not quality of service to customers, individuals or enterprises, which is one of the goals of cooperative banks, is a real issue. In the same way, the indivisible reserves, the steadiness of the share value, or the impossibility of external takeovers are among the main characteristics of the cooperative model and they are not taken into account by the financial analysis.

\section{References}

Ayadi, R., Llewellyn, D., Schmidt, R., Arbak, E., \& De Groen, W. (2010). Investigating diversity in the banking sector in Europe. Key Developments, Performance and Role of Cooperative Banks. Centre for European Policy Studies, Brussels, p. 168.

Birchall, J. (2013). Resilience in a downturn: The power of financial cooperatives, ILO.

Caire, G., \& Nivoix, S. (2012). La démocratie sociétariale vue d’en bas. Observations sur des assemblées générales locales de banques coopératives. Revue Française de Gestion, 220, 17-30.

Caire, G., Glémain, P., \& Nivoix S. (dir.) (2014). La place et les spécificités des banques coopératives et mutualistes en Pays de Loire. Rapport collectif de recherche-action 2012-2014 portée par la CRESS Pays de Loire-Observatoire régional de l'économie sociale et solidaire.

Fonteyne, W. (2007). Cooperative banks in Europe. Policy Issues. IMF Working Paper, 07/159, 68.

Groeneveld, J. M. (2013). Features, facts and figures of European cooperative banking groups over recent business cycles, EACB, p. 40.

GABV (Global Alliance for Banking on Values) (2012). Strong and Straightforward: The Business Case for Sustainable Banking, November, p. 16.

Lemzeri, Y., Jaeger, M., \& Ory, J. N. (2013). Cooperative versus conventional (joint-stock) banking in Europe: Comparative resistance and resilience during the recent financial crisis. International Conference on the Global Financial Crisis: European Financial Markets and Institutions, April 25-26, 2013 Southampton, UK.

Ory, J. N., Gurtner, E., \& Jaeger, M. (2006). La banque à forme coopérative peut-elle soutenir durablement la compétition avec la banque S. A. Revue Finance, Contrôle, Stratégie, 9(2).

Ory, J. N., De Serres, A., \& Jaeger, M. (2012). Comment résister à l’effet de normalisation: Le défi des banques coopératives, Revue des Sciences de Gestion, 258, 69-82.

Pourchet, A. (2011). L’hybridation du Business model des groupes bancaires coopératifs: Une étude comparée du groupe Crédit Agricole et du mouvement Desjardins. Master report, University of Paris-Dauphine. Retrieved on February 5, 2016 from http://www.recma.org/sites/default/files/memoire_alexandre_pourchet.pdf

Roy, J., \& Redjah, Y. (2012). A new database on financial services cooperatives: Description and first results. Working Papers CIRIEC, 2012(02), p. 24. 
Appendix. Capitalistic structure of the three cooperative banking groups (2012)

\begin{tabular}{|c|c|c|}
\hline \multirow[b]{2}{*}{$\begin{array}{l}\text { Individuals, employees, share } \\
\text { repurchases }\end{array}$} & $\begin{array}{l}6.9 \text { million associates, } 2512 \\
\text { locales banks }\end{array}$ & \multirow[b]{2}{*}{ 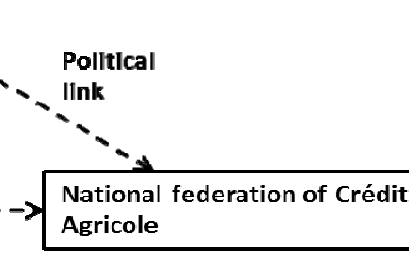 } \\
\hline & $\begin{array}{l}39 \text { regional banks, owning } \\
\text { CASA through the SAS Rue la } \\
\text { Boétie }\end{array}$ & \\
\hline \multicolumn{2}{|c|}{$43.7 \%$} & \\
\hline \multicolumn{2}{|r|}{ CREDIT AGRICOLE SA (2012) } & \\
\hline $\begin{array}{l}\text { Local banks } \\
\text {-Regional banks ( } 25 \% \text { of each } \\
\text { regional bank) } \\
\text {-Le Crédit Lyonnais (LCL bank) } \\
\text {-International banks } \\
\text { (Cariparma group, Crédit } \\
\text { Agricole Bank Polska, Crédit du } \\
\text { Maroc, Crédit Agricole Egypt) }\end{array}$ & $\begin{array}{l}\text { Specialized activities } \\
\text {-Specialized financial services } \\
\text { (Crédit Agricole Consumer } \\
\text { Finance, Crédit Agricole Leasing } \\
\text { \& Factoring) } \\
\text {-Asset management } \\
\text { (Amundi, CACEIS, Crédit Agricole } \\
\text { Assurances, Crédit Agricole } \\
\text { Private Banking, Indosuez Private } \\
\text { Banking, LCL Banque Privée) } \\
\text {-Specialized subsidiaries } \\
\text { (Crédit Agricole Capital } \\
\text { Investissement \& Finance, Crédit } \\
\text { Agricole Immobilier, Uni- } \\
\text { Editions, Crédit Agricole Cards \& } \\
\text { Payments) }\end{array}$ & $\begin{array}{l}\text { Investment bank } \\
\text { (Crédit Agricole CIB) }\end{array}$ \\
\hline
\end{tabular}

Figure 1. Crédit agricole.

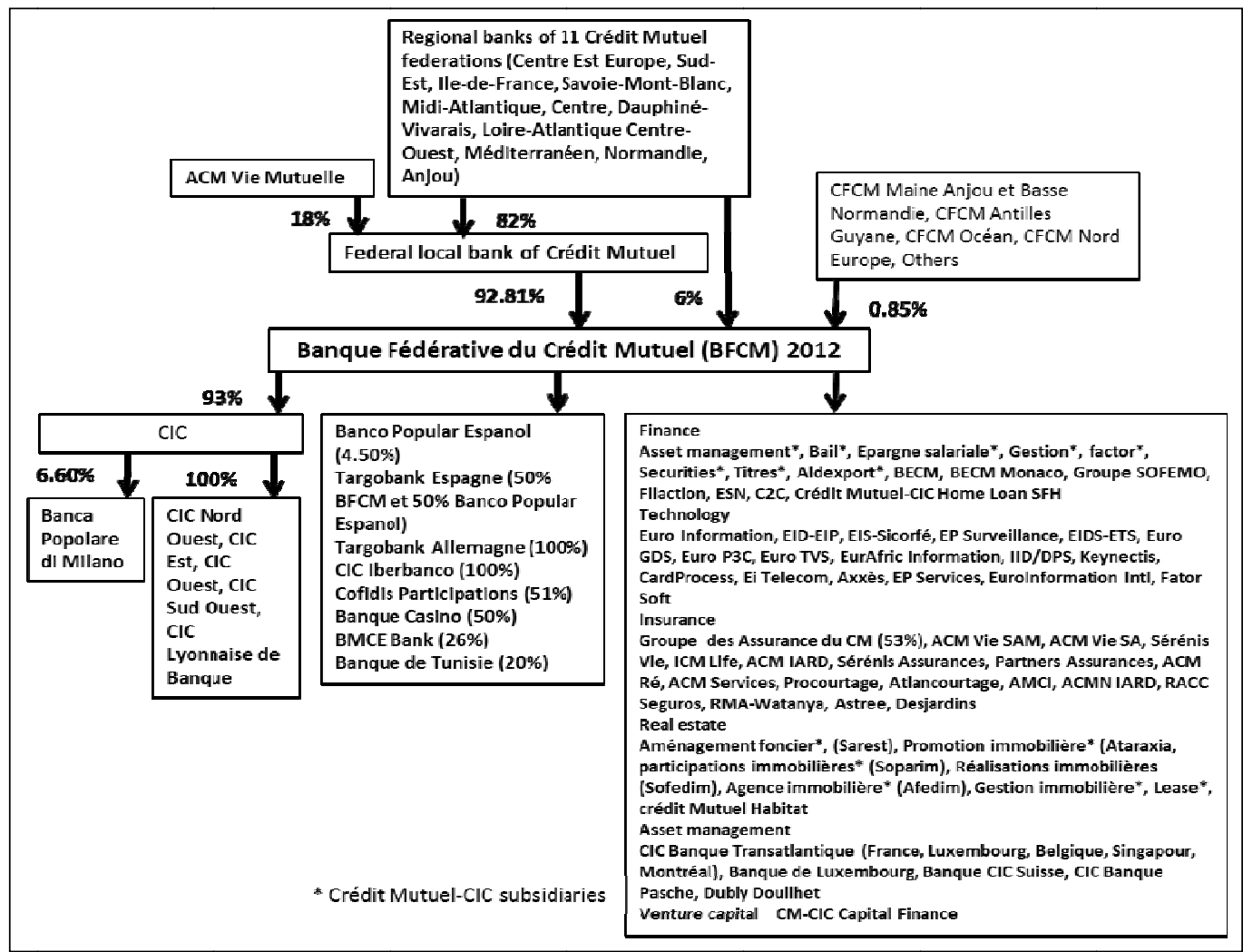

Figure 2. Crédit mutuel. 


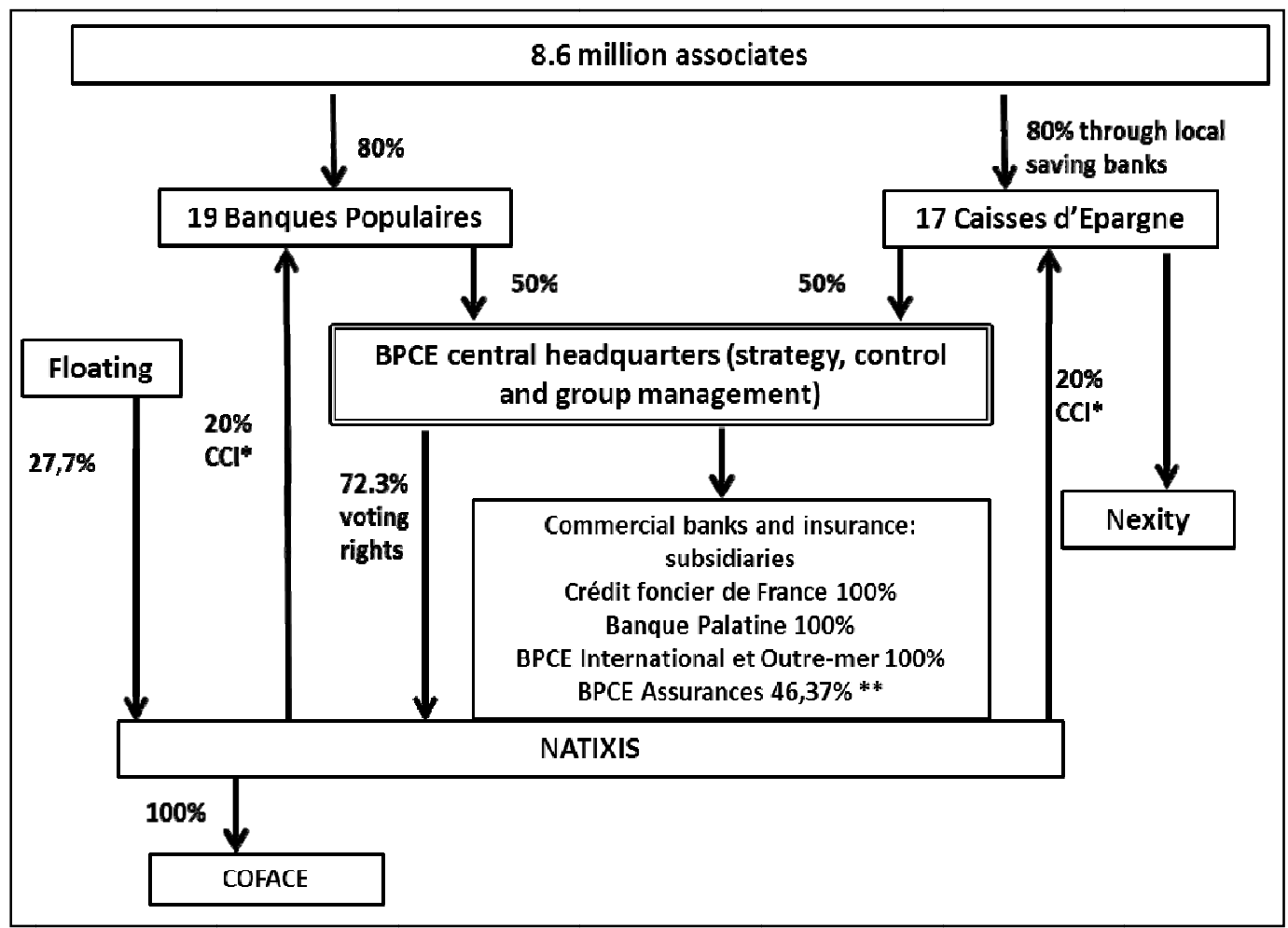

Figure 3. Banques Populaires Caisse d’Epargne (BPCE group). 